\title{
Análise das Interações em uma Ferramenta Síncrona sob a Ótica Bakhtiniana
}

\author{
Analysis of interactions in a synchronous tool \\ from the Bakhtinian perspective
}

Resumo: Este artigo pretende analisar os aspectos dialógicos e autorais de conversas síncronas a partir dos conceitos de Mikhail Bakhtin. Para tanto, apresenta fundamentação teórica sobre o dialogismo, a relação dialogismo e autoria, e a análise de trechos de conversas em um ambiente telemático.

Palavras-chave: Interação. Ambientes virtuais. Aprendizagem cooperativa.

Abstract: This article aims to examine the aspects of authorship and dialogic synchronous conversations from the concepts of Mikhail Bakhtin. For both, presents theoretical foundation on dialogism, the relationship dialogism and authorship, and analysis of fragments of conversations in an electronic environment.

Keywords: Interaction. Virtual environments. Cooperative learning.

ZANK, Cláudia et al. Análise das Interações em uma Ferramenta Síncrona sob a Ótica Bakhtiniana. Informática na Educação: teoria \& prática, Porto Alegre, v. 11, n. 2, p. $102-$ 112 , jul./dez. 2008.

\author{
Cláudia Zank \\ Universidade Federal do Rio Grande do Sul
}

Cristiani de Oliveira Dias

Universidade Federal do Rio Grande do Sul

Evandro Alves

Universidade Federal do Rio Grande do Sul

Karla Marques da Rocha

Universidade Federal do Rio Grande do Sul

Lilian Teresinha Johann

Unidade Integrada Vale do Taquari de Ensino Superior

\section{I ntrodução}

0 $s$ avanços tecnológicos engendram novas formas de pensamento, de atitude e de processos de ensino e aprendizagem. As tecnologias da informação e da comunicação, em específico as tecnologias digitais, são instrumentos que otimizam este novo paradigma e estão cada vez mais presentes nos espaços escolares, presenciais e a distância, demandando novas articulações entre o antigo e o novo; o ensinar e o aprender; o fazer e o refletir. Além disto, do ponto de vista técnico, o cenário amparado pelo desenvolvimento e utilização de tecnologias digitais se encaminha para a geração de espaços de lectoescrita e de trabalho cooperativo, no qual a interação oportuniza a construção compartilhada do conhecimento.

Contudo, além do desenvolvimento técnico, faz-se também necessário um deslocamento de abordagem teórica do sujeito que 
está usando tais tecnologias. Somente assim poder-se-á postular metodologias e posturas de trabalho pedagógico que se pretendem interativas nos espaços proporcionados pelas tecnologias no contexto escolar. Um sujeito que não é apenas um conjunto de regras de movimentação do olhar, de articulações dos dedos e de audição mensuráveis. Ainda que tais mensurações sejam importantes para a constituição de espaços providos pelas tecnologias, o sujeito não se restringe a elas.

Para além desses itens, o conceito de sujeito, neste trabalho, constitui-se em uma integração indivisa entre mente e corpo, razão e emoção. Sujeito que constrói a si mesmo mediante a relação com o outro, desenvolvendo sua capacidade de expressar-se, em nosso caso específico, falando ou escrevendo, na mesma medida em que constrói a sua relação como ouvinte ou leitor do outro. Sujeito que ensina e aprende, é aluno e professor, presencialmente e/ou a distância, mediante a função social da linguagem, redundando em relações de ensino e aprendizagem constituídas na indissociabilidade entre a cognição e a produção de sentido (AXT; MARASCHIN, 1997).

Esta tentativa de deslocamento é o que este artigo se propõe, a partir da análise de um corpus de dados referente às produções realizadas mediante tecnologias digitais síncronas em um ambiente virtual de aprendizagem num contexto acadêmico do Ensino Superior $^{1}$. Para operar esta análise, utilizam-se apontamentos teóricos da filosofia da linguagem de M. M. Bakhtin, sobretudo no que tange aos conceitos de dialogismo, autoria, polifonia e de alteridade.

O artigo pretende analisar os aspectos dialógicos e autorais de conversas síncronas a partir dos conceitos bakhtinianos. Na seção dois, realiza-se uma breve discussão sobre filosofia de M. M. Bakhtin, com foco no conceito de dialogismo e autoria. Na seção três, tais conceitos são discutidos em um contexto mais próximos de nosso estudo, referente a ambientes telemáticos e suas ferramentas

\footnotetext{
${ }^{1}$ As referidas produções, corpus de dados do presente estudo, fizeram parte das aulas da disciplina Produção em Ambiente Telemático na Visão Ético-Estética de Bakhtin, ministrada pela professora Margarete Axt, docente do Programa de Pós-graduação em Educação da Universidade Federal do Rio Grande do Sul (UFRGS). Foram analisados os registros dos chats produzidos através na funcionalidade Bate Papo do ambiente virtual de aprendizagem Teleduc. O ambiente Teleduc está disponível em: <http://teleduc.cinted.ufrgs. $\mathrm{br} / \sim$ teleduc/pagina_inicial/index.php?>
}

de interação síncrona. Na seção quatro, analisam-se alguns registros do corpus sob a perspectiva teórica apresentada. Na última seção, são apresentadas as considerações finais.

\section{Dialogismo em M. M. Bakhtin}

Durante sua vida, o pensador russo M. M. Bakhtin (1895-1975) dedicou-se a diversas áreas de estudo: filosofia, análise literária, marxismo, psicanálise. No entanto, o corpo de sua obra sempre teve como temática central uma abordagem filosófica acerca dos fenômenos da comunicação verbal, denominada dialogismo.

O dialogismo é uma formulação que se antepõe, de um lado, a corrente formalista de análise dos fenômenos da linguagem; de outro, à filosofia idealista decorrente do pensamento filosófico idealista, sobretudo no que se refere à conformação da subjetividade como um processo que possa ser generalizado a priori a todos os seres humanos.

Na Rússia da década de 1920, pós-revolução soviética, os estudos sobre Literatura e Lingüística advêm do formalismo russo ${ }^{2}$. Em linhas gerais, o posicionamento dos formalistas era de que arte e literatura não serviriam a fins externos, mas encontravam suas justificativas e leis intrínsecas em si próprias (TODOROV, apud BAKHTIN, 2003), atribuindo ao leitor e ao autor um papel de segundo plano na análise da poesia e da literatura. Os formalistas praticavam e defendiam a estética do material, dando ênfase à forma. Esta foi, no entanto, a maior crítica de Bakhtin aos Formalistas, pois, para ele, a verdadeira noção da pesquisa estética deveria ser a arquitetônica, ponto de encontro e de interação entre material, forma e conteúdo (TODOROV, 2003).

A relação entre Bakhtin e o idealismo, sobretudo com a obra de Kant, é bastante complexa e foge aos objetivos deste trabalho detalhá-la exaustivamente. Neste sentido, sumarizamos

\footnotetext{
2 O formalismo russo é uma escola de pensamento bastante diversa que ficou conhecida por ter logrado dar especificidade e autonomia aos estudos da linguagem poética e da literatura. Entre seus integrantes destacam-se, por uma subdivisão chamada de formalismo orgânico, (em que o fenômeno literário assemelhar-se-ia e a relação entre corpos orgânicos), Vladimir Propp e sua Morfologia dos Contos Russos. Por outra subdivisão, a do formalismo linguístico, destacam-se o trabalho de Roman Jakobson e Yuri Tynyanov. O legado dos formalistas é imenso, dentre eles o de serem precursores de outras escolas de pensamento, como a Escola de Praga e o Estruturalismo, já nas décadas de 1950-1970.
} 
os apontamentos de Sobral (2005), que afirma Bakhtin ter operado uma ressignificação das teses de Kant e seus seguidores. Em linhas gerais, Bakhtin (2003) mantém, para a análise da obra literária, as duas principais categorias kantianas: o tempo e o espaço; contudo, atualizaria tais categorias para um contexto relativístico einsteiniano, em que espaço e tempo se afetam, ao formular o conceito de cronotropo. Além disso, Bakhtin (2003) afirma que os sujeitos se configuram como tais não antes ou a parte do uso efetivo da linguagem, como é proposto por Kant e seus seguidores, mas durante o transcurso da interlocução. Assim, a análise do fenômeno da comunicação verbal deve considerar a especificidade em que a interlocução acontece.

Assim, em contraponto às correntes formalistas e idealistas, Bakhtin, já desde seus escritos da juventude, busca outras alternativas para estudos que tratam do fenômeno da linguagem. Nesta tentativa, ao longo de sua obra, Bakhtin procurou delinear uma abordagem de investigação e análise que é denominada dialogismo. Esta perspectiva seguiria, dentre outros, os seguintes princípios:

(1) A linguagem, ainda que detenha sua especificidade e leis intrínsecas, não se define ou se justifica em si mesma. Tais especificidades e regras são sensíveis a fatores que não são linguagem (políticos, sociais, culturais, tecnológicos etc.). Por este motivo, atribui-se a Bakhtin a formulação de uma translinguística, isto é, uma abordagem da linguagem cuja imagem se encontra para além da de um sistema fechado, o que prenuncia, por exemplo, estudos sobre o tema a partir de teorias da complexidade, tais como o exposto por Fiedler-Ferrara (1997).

(2) A sensibilidade da linguagem ao que lhe é exterior aponta para uma caracterização de sua materialidade, registros orais ou escritos, não como uma materialidade regida por leis intrínsecas e tampouco como elementos que se possam generalizar a todos os sujeitos da linguagem. A linguagem e seus fenômenos são, sobretudo, expressividade sensível ao tempo, espaço e relações entre interlocutores (falante-ouvinte, autor-leitor), de forma que todo o fenômeno da linguagem é indissociado de sua função comunicativa, é sempre composto em entremeio movimento de comunicação verbal.

(3) Os dois pontos anteriores apontam para a relação do fenômeno da linguagem e seu contexto. Ainda que, na obra bakhtiniana, o enunciado seja sensível a condição espaço-temporal, a relação entre esse e o contexto que Ihe circunda é também complexa, sendo muito difícil apontar relações causais isoladas entre texto e contexto.

(4) O fenômeno da linguagem é um fenômeno eminentemente intersubjetivo. Para Bakhtin, é mediante trocas de enunciados, orais e escritos, que os sujeitos se constituem como tais, definindo-se a si mesmos na relação com o outro. Este tema aparece já no primeiro ensaio publicado de Bakhtin, Arte e Responsabilidade: “O eu necessita da colaboração dos outros para poder definir-se e ser autor de si mesmo." (STAM, 1992, p. 17)

No prefácio à edição francesa de Criação da Estética Verbal, Todorov (2003) indica uma idéia inicial para a concepção bakhtiniana de dialogismo: direitos iguais entre autor e personagens. Este foi o ponto que chama a atenção de Bakhtin no seu estudo sobre Dostoievski. Até então, Bakhtin observa que a relação entre autor e personagens era constituída desigualmente, de tal maneira que os segundos nada mais eram que porta-vozes da voz do autor. O autor tudo sabia sobre seus personagens: bons e maus, mocinhos e vilões estão ali para seguir o destino traçado pela intriga e representar, na intriga, a voz do autor. Neste registro de composição da obra literária, que Bakhtin denomina de monológico, há um excedente da visão estética (exotopia) na direção do autor para o personagem, mas o movimento inverso não ocorre. Ou seja: a personagem é totalmente devassável pelo autor, e o autor é um absoluto inacessível aos personagens.

Com Dostoievski, Bakhtin desvela outra maneira de o autor se relacionar com as personagens na obra literária. Neste registro, ele parece não mais comandar integralmente a obra, bem como o dizer e a interioridade das personagens. Obviamente, o autor continua tendo a função pragmática de usar sua voz para organizar a obra literária; porém, sua voz é mais uma dentre outras vozes que se con- 
gregam na obra. E esta modificação na relação composicional implica modificações até na forma de escrever e de apresentar personagens e tramas. Assim, os direitos iguais que menciona Todorov (2003) dizem respeito à obra literária ser um espaço-tempo em que se defrontam pontos de vistas entre personagens e no qual o autor é somente uma voz a mais. Neste registro de composição da obra literária, o qual que Bakhtin atribui o nome de polifônico, há reciprocidade de excedente de visão estética entre autor e personagens. Em suma, as relações dialógicas têm lugar quando há um registro polifônico de composição literária, e este registro é extremamente sensível à reciprocidade de excedente de visão estética entre autor e personagens.

Embora Bakhtin, segundo Faracco (2005), após o estudo de Dostoievkski, não volte mais a utilizar o termo polifonia como operador de análise literária em sua obra, o mecanismo dialogismo-polifonia-exotopia parece ter sido exponenciado quando, já ao final da vida, Bakhtin escreve sobre aspectos metodológicos das ciências humanas (BAKHTIN, 2003). Para Bakhtin, nas ciências humanas, a reciprocidade de excedente de visão estética entre pesquisador e pesquisado é inerente à própria relação. Anda que seja o pesquisador o autor pragmático do trabalho, ele não sabe tudo sobre seu pesquisado e vice-versa. Assim, é muito difícil se ter uma palavra originária ou uma palavra final sobre qualquer pessoa ou assunto, mesmo que sobre ele nos debrucemos uma vida inteira. Isso porque não temos acesso a tudo o que a pessoa disse ou pensou, ou tudo o que foi dito ou escrito sobre determinado assunto. E, mesmo que tivéssemos tal acesso, nada assegura a exatidão de nosso esforço de compreensão.

Em um primeiro momento, tal inacessibilidade e insegurança quanto à exatidão poderiam ser encarados como um desestímulo à pesquisa, pela impossibilidade de generalização. Contudo, para Sobral (2007, p. 114 et seq.), Bakhtin aponta exatamente para esta configuração como sendo uma forma de entravar outras relações entre pesquisador e pesquisados, enlaçando, com maior organicidade, aspectos éticos e estéticos à atividade de pesquisa.

Para Sobral (2007), o pesquisador tende entre suas expectativas para com o fenômeno, seu encontro com a realidade da pesquisa e com os referenciais teóricos do estudo.
Num marco da pesquisa tradicional, a atividade de pesquisa tende a enquadrar à realidade estudada a um marco teórico previamente definido, no atendimento das expectativas do pesquisador, cuja neutralidade faz com que à realidade se enquadre como ilustração ou não de determinado modelo teórico. O convite feito por Bakhtin é que o pesquisador tenha claras as suas questões, ao mesmo tempo em que reconheça de que à realidade da pesquisa pode levá-lo ao insuspeitado, em nome da coerência do estudo. “Em suma, do equilíbrio entre a especificidade e a generalidade com que trata o fenômeno na construção do objeto, e entre sua inserção autoral - mais próxima ao objeto - e as bases teóricas de que parte - que tendem à generalidade [...] - depende a coerência da pesquisa." (SOBRAL, 2007, p. 115)

Essa postura exige um deslocamento também do pesquisador, mediante a qual a análise do enunciado em dada circunstância possibilita investigar em outro registro as complexas relações do encontro entre texto e contexto; e, em termos mais amplos, entre linguagem e vida. Desta maneira, teríamos indícios e inferências de como, em determinadas circunstâncias, delinearam-se correntes dialógicas e de como sentidos foram nestas produzidos e negociados. Além disso, pela análise desta configuração, pode-se também inferir como os sujeitos constituem, neste contexto específico, aos outros e a si mesmos como interlocutores e, enquanto função derivada desta interlocução, como autores.

Desta forma, para Bakhtin, as verdades sobre si, sobre o outro e sobre o mundo não seriam nem entes materiais nem abstrações a priori. Elas são construções relacionais entre sujeitos interlocutores, falantes-ouvintes, autores-leitores, presenciais ou a distância, em eventos síncronos e assíncronos, num movimento dialógico em que o enunciado, enquanto unidade fundamental da comunicação discursiva (BAKHTIN, 2003, p. 269), inserese nas correntes dialógicas. Esta inserção se dá pela conexão estabelecida entre o cronotropo do enunciado presente a outros cronotropos, passados e futuros. Tal conexão se dá na conformidade em que o enunciado é sempre, no momento em que se presentifica, um tipo de réplica a outros que o antecederam, encaminhando-o ao (que foi dito no) passado. Ao mesmo tempo, o enunciado presume, no momento de sua construção, potenciais trépli- 
cas ao que está sendo enunciado naquele momento, o que o encaminha ao (que se dirá no) futuro. Assim, para Stam (1992), o dialogismo bakhtiniano pode ser definido como a relação necessária entre um enunciado e outros enunciados. Stam (1992) deixa claro ainda que o enunciado deve ser considerado no sentido de ser pleno de ecos de outros enunciados, os refutando, confirmando e complementando. O enunciado se carateriza por sua responsividade, isto é, ser, ao mesmo tempo, uma resposta a enunciados passados e por deixar em aberto uma pergunta a futuros enunciados.

No contexto dos enunciados, o dialogismo seria, então, um fluxo que permeia as relações entre dizeres próprios alheios; torna-se mais visível, no âmbito da literatura. Mas o dialogismo permearia outras instâncias sem ser a da literatura. Para Bakhitn, o dialogismo é um processo social mais amplo, que atinge toda a comunicação verbal, e do qual a polifonia encontrada no romance é apenas a parte tornada visível na arte literária. Assim, o dialogismo também permearia as relações entre dois enunciados na vida cotidiana, entre dois dizeres/escreveres que distam um do outro, no tempo e no espaço, mas que integram, como réplicas e tréplicas, ao diálogo incessante e inacabado, o tipo mais notório e simples de relação dialógica.

Nesse sentido, numa nota metodológica, são produtivas as relações estabelecidas entre a criação estética, os conceitos bakhtinianos e o chat - ambiente cuja construção discursiva se fundamenta na alternância enunciativa dos sujeitos. No caso específico, trata-se de interlocutores radicalmente distintos num registro de um chat ocorrido no contexto de uma disciplina de pós-graduação no Ensino Superior.

Os apontamentos feitos por Bakhtin são essenciais para a análise das produções no referido ambiente.

Assim, a linguagem pragmaticamente constitui os sujeitos durante interlocução. O enunciado, enquanto marca de identidade social, é um elo na cadeia da comunicação verbal, grande teia inconclusa de origem indefinida. $\mathrm{O}$ dizer do outro é sempre o ponto de partida para a minha palavra; é ele que me integra e é com ele que interajo, colocando-me em relação a um sujeito/ouvinte/respondente, de quem a minha palavra - assim como eu - espera uma atitude essencialmente responsiva (BAKHTIN, 2003). A responsividade - legitimi- dade enunciativa do(s) sujeito(s) em relação ao(s) enunciado(s) de outrem - inerente à palavra e ao homem, é ingrediente fundamental da linguagem, desta teia maior, entrelaçada/ fiada em processos múltiplos e plurais de autoria. É o inacabamento da palavra, do enunciado do outro, que permite a manifestação de opiniões, considerações, discordâncias, válidas e importantes à construção informativo-histórica.

O outro - que me integra - é, a um só tempo, o responsável pelo meu dizer e o alvo do que enuncio; ambos participam da configuração da referida zona de opacidade, decorrente da sobreposição, num processo de interação/ inter-relação e mediação, (re-)posicionam-se, (re-)elaboram, (re-)significam seus olhares, e transformam - em menor ou maior grau -, contextual e cooperativamente, a história. A ausência de uma voz predominante, superior e as perpétuas trocas (STAM, 1992) trazem à luz uma nova concepção - bakhtiniana - de autoria, tema sobre o qual tratará a próxima seção.

\section{Dialogismo e Autoria em Ambientes Telemáticos}

Responsável pela interação entre a vida e a língua, o enunciado - manifestação da linguagem e unidade da comunicação verbal -, essencialmente multiforme e responsivo, ganhou novo habitat - o chat -, no qual a polifonia pode ser entendida e vivenciada sob a ótica que lhe é própria: o dialogismo.

Os chats - meio de promoção das conversas instantâneas - , retratado por Bernardes \& Vieira (2001) e Axt (2006), ao fundir elementos da oralidade e da escrita, dá (dão) origem a um gênero ${ }^{3}$ híbrido, essencialmente polifôni-

\footnotetext{
${ }^{3} \mathrm{Na}$ concepção de Bakhtin (1997b), os gêneros discursivos são decorrência direta das formas representativas do mundo cotidiano e prosaico; por isso, estão ligados à variedade virtual e à inesgotabilidade das próprias atividades humanas que variam segundo o espaço/tempo. Os gêneros são por ele classificados em primários (simples - réplicas do diálogo, relatos cotidianos, cartas, diários, - formam-se nas condições da comunicação discursiva imediata) e secundários (complexos - romances, dramas, pesquisas científicas, - surgem nas condições de um convívio cultural - escrito - relativamente muito desenvolvido e organizado [...] no processo de sua formação, incorporam diversos gêneros primários) Os gêneros são dados na cultura e nela se inter-relacionam; representam suas unidades abertas e são depositários de formas particulares de ver o mundo. O gênero chat é construído a partir da fusão dos gêneros primários e secundários, e compreende a concretização da reunião de vozes (polifonia) abordada pelo autor.
} 
co, onde as vozes podem se relacionar, investigar-se, consolidando conceitos, acentuando divergências, mas, sobretudo, interagindo e exercitando uma autoria - individual e coletiva -, própria de sujeitos discursivos, que, da sua posição, manifestam, através da troca de enunciados, sua identidade social. O chat, deste modo, potencializa uma experimentação polifônica síncrona e promove o diálogo entre essências enunciativas: o corpóreo-físico é substituído pela materialidade discursiva; constituise a presencialidade do ser, responsável pela interação entre/através do(s) discurso(s).

O sujeito, desta forma, é concebido em sua essência; visto, considerado e analisado em sua materialidade discursiva, o que revela uma reconfiguração das constituições metodológicas. A presencialidade não se restringe ao estar na aula, ao estar vendo/assistindo a, mas exige, fundamentalmente, o interagir com, o expressar-se a partir de, o que pressupõe a reflexão, o diálogo - real e concreto - , a manifestação ativa e crítica. O sujeito é entendido nos ambientes interativos através do que diz, enuncia; o enunciado constrói e (re-)define sua identidade social - polifônica e mutável.

Os ambientes telemáticos são espaços de reterritorialização dos sujeitos, identidades e relações. Paralelamente à teia gigantesca e inconclusa da comunicação verbal analisada por Bakhtin (2003), é tecido, conjuntamente, um discurso cooperativo, produto da reflexão, do diálogo interior - entre as consciências que constituem o sujeito, e exterior - entre os leitores-respondentes. Trata-se de uma aliança teórica, social, crítica e pedagógica, cujo mecanismo dialógico orienta a apreensão do saber a partir da contribuição legítima e essencial dos interlocutores - exemplo notório do exercício de autoria. Os sujeitos, num diálogo com os outros que Ihe antecederam na cadeia semântico-histórica, interagem com os colegas virtualmente e discursivamente materializados, graças ao caráter responsivo ${ }^{4}$ do enunciado. Esta aliança, que desfaz a crença monológica através da caracterização de uma realidade de aprendizagem polifônica, baseiase na ajuda mútua, no suporte de conhecimentos, nas considerações individuais acerca

\footnotetext{
4 “Incompletude que possibilita que se oponha à palavra do locutor uma contrapalavra, à qualquer tempo, compreendendo, reconstruindo, re-significando e complementando o posicionamento do outro, a partir de uma situação/ condição de (re-) leitura particular." (BAKHTIN, 1999, p. 132)
}

de objetos sociais, que são estudados e investigados no coletivo.

O diálogo entre o eu e o outro, entre muitos eus e muitos outros é, para Bakhtin, atividade elementar da linguagem - construção criativa e coletiva - , o que suplanta a concepção descontextualizada do sistema abstrato (STAM, 1992). Nesse sentido, a alteridade permeia os processos de autoria - leitura e escrita -, já que orienta o olhar dos autores, diversifica as interpretações/ posturas subjetivas e promove a evolução a partir das divergências e colocações, sempre complementares e relevantes à construção discursiva do conhecimento, enquanto processo permanente.

Assim, ferramentas síncronas, como o Bate Papo, aliadas a metodologias que promovem as interações dialógicas (AXT, 2006) num ambiente educativo, proporcionam aos participantes ricas experimentações polifônicas. Há sempre a possibilidade de interferência/interação entre sujeitos, dizeres, leituras - interpretações. A escrita passa a ser um processo constante de construção e reconstrução, no qual a palavra revela seu caráter criativo. As contribuições - manifestações claras de autoria - são individuais e coletivas; nas articulações dos vários sujeitos, percebe-se que cada um é complemento necessário do outro (BAKHTIN, 2003).

Autoria e dialogismo serão retomados na próxima seção. Por meio da análise de trechos de chats, pretende-se favorecer o entendimento dos ambientes telemáticos a partir da ótica de bakhtiniana.

\section{Análise de Conversas Síncronas}

Esta seção apresenta a análise de trechos de chats que ocorreram durante a realização da disciplina Produção em Ambiente Telemático na Visão Ético-estética de Bakhtin (2008/01), a qual faz parte do Programa de Pós-Graduação em Educação (PPGEDU/UFRGS) e tem como objetivo trabalhar com conceitos da filosofia da linguagem de Bakthin como forma de apreciação da produção de grupos de trabalho em ambientes telemáticos.

A disciplina realizou-se na modalidade semipresencial. Os encontros à distância ocorreram por meio de chats, realizados no ambiente virtual de aprendizagem (AVA) Teleduc. Selecionou-se, dentre um universo de dez encontros virtuais - e em virtude da produtividade da 
discussão empreendida pelos vinte participantes - , um encontro, em particular. A partir deste corpus inicial, foram eleitos temas centrais (contemplados nas palavras-chave deste artigo), e destacadas as trinta e cinco interações que se estabeleceram em torno deles. Estes assuntos, bem como os dizeres proferidos pelos sujeitos, serviram de objeto de estudo para a análise que se apresenta.

O primeiro tópico se refere à desmistificação da crença em verdades absolutas: a partir das considerações de Mikhail Bakhtin (2003), percebe-se que, conforme prévia abordagem teórica, o chat compreende a concretização do dialogismo entre os interlocutores, isto é, a desconstituição da crença em verdades absolutas. Cada sujeito tem a possibilidade de lançar discussões; não se espera, necessariamente, do professor (Ave) a iniciativa de/para tudo. Ele, no seu papel de organizador, interage com os alunos e pontua o(s) diálogo(s), a exemplo do que ocorre nas obras de Dostoievski, entre autor e personagens; o professor, no chat, não tem acesso ao inconsciente dos mesmos, nem pretende regulá-los; ele apenas acompanha a interação, aprofunda discussões e lança novas problematizações em face do que está sendo discutido:

(16:07:59) Irc fala para Todos: pessoal, já que só reclamam e não iniciam a discussão, lanço a vocês a pergunta sem resposta na aula passada: "Onde começa a conversa para Bakhtin?"

(16:29:18) Ave fala para Todos: estamos aqui, conversando neste chat e nossas falas vão sendo gravadas desordenadamente, "perdendo a seqüência". Será que nas aulas presenciais "seqüenciadas" as coisas não ocorrem mais ou menos da mesma maneira... fico pensando na atuação do professor como um seqüenciador do discurso pedagógico. Alguém embarca nesta discussão?

(16:30:38) Mis fala para Ave: Sim, acho q o bom professor faz esse papel de seqüenciador, mas sempre tem algo que "escapa" a ele que são justamente as conversas "paralelas"

(16:56:27) Ave fala para Todos: antes de comentar a mensagem do Dna, ficou claro para todo mundo o lance de como a "palavra do outro" se transforma em "minha palavra"?

Um processo cooperativo acontece quando cada qual vê na palavra do outro um suporte, um complemento para a sua compreensão, o que revela relações dialógicas, tecidas em função desta busca pelo entendimento, objetivo comum. A reflexão e a autoria são ações polifônicas - em função das múltiplas vozes que convivem no indivíduo -, e plurais/dialógicas, já que todo enunciado completa dizeres anteriores - de colegas, do professor, dos vários outros que comungam esta ânsia pelo entendimento. A aprendizagem é um processo individual, que nasce do coletivo - motivado pela responsividade plantada por outrem -, e no coletivo desemboca; é produto da interação entre os sujeitos, que re-significam a si e ao já dito, imprimindo a marca de sua identidade social. No trecho abaixo, pode-se visualizar como se processa a aprendizagem cooperativa, por meio da reflexão e da autoria que acontecem coletivamente:

(17:00:37) Nai fala para Todos: a nossa palavra se constitui a partir da(s) palavra(s) do(s) outro(s) (17:01:26) Irc pergunta para Nai: então toda nossa criação é social?? (17:02:55) Nai fala para Todos: sim, isso tem a ver com aquela citação sobre o Adão, que o Gua mencionou antes ... que ninguém tem uma idéia inédita/ original.. ela é sempre produto do diálogo que estabelecemos com o que nos constitui enquanto sujeitos da linguagem (tradições/ crenças/ padrões/ teorias/ vivências....) (17:10:52) Ait fala para Ave: Tenho a impressão de que sempre a palavra do outro se torna minha palavra, nosso discurso é carregado por aquilo que lemos e ouvimos (palavra do outro). (17:14:04) Tel fala para Todos: concordo com - Ait, acabamos nos apropriando de terias que lemos e que ouvimos, e isso faz com que a palavra do outro se torne a minha palavra... (17:18:29) Ait fala para Tel: Mas sendo assim nada do que falamos é dotado de originalidade, será que tudo não passa de repetição?

(17:19:23) Ave fala para Todos: Permitam-me uma citação da p. 293, sobre a questão que alardeei: "As palavras da língua não são de ninguém, mas ao mesmo tempo nós as ouvimos apenas em determinadas enunciações individuais, nós a lemos em determinadas obras individuais, e aí as palavras já não têm expressão apenas títpica porém experessão individual externada com maior ou menor nitidez (em função do gênero), determinada pelo contexto individual do enunciado. [...]

(17:28:06) Nai fala para Todos: o entendimento se dá na fronteira entre o que o leitor diz e o que eu digo a respeito do que ele disse; a leitura nunca é um espelho do dizer do outro, mas uma reconstrução a partir dele.

Além disso, as respostas às dúvidas dos outros são uma forma de reforçar ou questionar 
os significados apreendidos, possibilitando que os demais participantes - ativos, ainda que calados e discursivamente ausentes -, possam se beneficiar deste apontamento no seu processo de reconstrução/(re)leitura. Sentimentos de confusão, dificuldade, tristeza são compartilhados, e, no grupo, estabelece-se uma união de identidades, que, amparadas uma na percepção da outra, direcionam os seus dizeres, na interação com os demais, assimilando sentidos complementares. Exemplo disso é a colocação Estou aprendendo muito com vcs. (16:59:27), em que AID manifesta a relevância do que enunciam os outros - parceiros legítimos - para o seu processo de aprendizagem:

\begin{abstract}
- Oi AID, to me debatendo com o Bakhtin - Nós estamos, colega, nós...rsrsrs - Vejo que as meninas que já estudam estão tirando de letra... a gente vai penar umpouco mais ... hehehe SIR responde para AID: Pois é, sabes que essa parte de linguistica não faz meu tipo, tenho dificuldade para entender, venho da área de exatas...imagina só a tristeza!!! Rsrsrs (16:55:27) AL fala para AID: Que isso, AID! Faz como a professora ET disse: “Te joga!" (risos)... (16:56:40) AID fala para AL: rsrsrs, tô tentando (16:58:30) AM fala para AID: Oi A! Também acho que Bakhtin não é fácil... comecei a estudá-lo junto com uma turma de EAD tb... é muito legal, vamos aprendendo uns com as dúvidas, leituras e questões dos outros (16:58:51) NAl Sai da sala... (16:59:27) AID fala para AM: É, AM, estou aprendendo muito com vcs!! ;-)
\end{abstract}

O chat situa o sujeito num contexto diverso de autoria; novas necessidades de expressão sugerem e apontam para criativas possibilidades lingüísticas, que promovem a impressão discursiva do extraverbal: revelam-se risos (risos, hehehe, rss), tensão e ansiedade em encontrar uma solução para problemas da ordem do sentido ("??!!"); propaga-se uma consciência de inacabamento do enunciado, cuja edificação e organização está em curso [“; -)” e “..."] e é produto de um trabalho coletivo e individual.

(16:52:23) Mac fala para Ave: Pardon, professeur! Só estavamos treinando as 2 frases que decoramos até agora! huahauhauhau... (16:53:50) Ait fala para Sek: de nada Sek!! E parabéns pelo bacuri!! Gremista certo neh!! (16:56:29) Sek fala para Ait: Sim, com alergia a gremista...rsrsrsrs (17:02:10) Mac fala para Ait: Êeeee! Agora podemos fazer um grupo de "conversação", viu? A Gam tbentra... :0)
Também a questão da presencialidade pode ser analisada enquanto essência discursiva a partir das reflexões direcionadas à questão do gênero chat, definido como gênero híbrido (AXT, 2006), graças à fusão de elementos da oralidade e da escrita. O corpóreo-físico não reflete a presença; ela é assegurada, ainda que de forma relativa - já que é possível ler e interagir, sem se manifestar junto aos demais - pela materialidade enunciativa. Estar presente, manter-se na sala, não significa estar interagindo com (todos) os colegas que dela participam; são muitas as linhas de discussão, o que diversifica os canais/ focos de atenção, e resulta em interrupções e retomadas do sentido. A temporalidade no chat é questão problemática; como todo tempo é tempo de ler e se manifestar, irrestritamente, sem que haja uma ordem monológica, uma seqüência de ações seguida por todos, faz-se necessário selecionar o que mais interessa e se posicionar a respeito; a ausência ou a elaboração de um dizer implica a não-leitura dos que vão sendo enunciados:

(15:37:10) Gua fala para Ram: É isso mesmo - e com nosso entra e sai, fica uma conversa de loucos, sem que a maioria saiba o que foi dito antes. (15:46:28) Dna fala para Ave: Pessoal, fui ao banheiro e ao voltar não estou entendendo mais nada. Osgrupos são os mesmos da proposta feita anteriormente? Ou seja, construção coletiva do memoril de conceitos? (16:25:13) Leb fala para Todos: Que livro Mac? Algo me diz que pego tudo pela metade, porque fica difícil acompanhar como uma seqüência. (16:31:52) Irc fala para Ave: Ave, acredito ser o caos que a professora Margarete falou no primeiro dia de aula, não tem como o professor controlar os debates e discussões dos alunos (16:57:19) Irc fala para Ave: criatura, eu vi tanto "oi fulano""oi beltrano" que não peguei essa questão, não ficou claro...eheheh

Conforme coloca Stam, em citação já mencionada, o dialogismo representa "[...] a relação necessária entre um enunciado e outros enunciados [...]" (STAM, 1992, p. 53), distantes no tempo e no espaço, mas semanticamente ligados, relacionados; cada um - produto da posição/condição de seus enunciadores/leitores-respondentes - existe no todo e a partir deste; cada dizer - resultante de um diálogo múltiplo e plural - , constitui um elo que, juntamente com os demais, forma uma corrente discursiva - inconclusa e de origem indefinida -, em torno de um texto maior - a Estética da Criação Verbal, de Bakhtin -, que, por sua 
vez, nos remete a outros contextos textuais. Em outras palavras, cada sujeito estabelece relações entre Bakhtin (objeto de estudo) e os outros já conhecidos, estudados; cada sujeito se apóia em autores e conhecimentos já assimilados, auxiliares no entendimento da teoria bakhtiniana. Essa evocação intertextual fica evidente nos enunciados abaixo, em que se estabelecem relações entre conceitos de Bakhtin (2003) e Vygostky (1998):

(18:17:04) Gam fala para Todos: Bakhtin escreve que a palavra é a arena das transformações sociais. Ele também diz que cada palavra tem uma vida de palavra, uma história. Parece que assim ele vai falando da transformação também da palavra. (18:17:30) Irc fala para Sor: é a operação psicológica reversa para vygotsky... (18:18:26) Sor fala para Todos: Irc - Vygotsky formação social da mente, dá uma olhadinha ele coloca a influencia do social na formação.

As reflexões e a sistemática estabelecidas no bate-papo apontam para o todo, numa visão global - de sujeito, de linguagem, de conhecimento. Neste sentido, ao texto/ diálogo ligase o contexto - interior (entre consciências) e exterior (entre leitores-respondentes) - que o originou/ orientou; a compreensão, como bem colocam EN e AM (16:53:45 e 17:01:34) é um processo permanente; todo dizer é relevante e enriquece a histórica construção do conhecimento, teia infinita tecida por cada um de nós:

(16:53:45) EN fala para AM: acho q falta mais leitura pra definir melhor alguns conceitos (17:01:34) AM fala para EN: concordo EN... os conceitos vão sendo trabalhados ao longo da disciplina, e a nossa compreensão vai sendo construída também... hoje ao reler o texto, já o vi de uma outra forma... cada leitura suscita novas interpretações dos conceitos... é bem interessante.

Todo diálogo é um processo múltiplo/dialógico e plural/polifônico; todo enunciado é produto de um processo que nos engloba, restringe e alimenta: engloba porque somos parte dele; restringe, pois falamos a partir do conhecimento polifônico que temos do todo; alimenta ao nos premiar com a figura do outro, e o (seu) rastro responsivo que nos move e instiga a questionar, complementar, (re-)criar. O chat, assim, pode ser entendido enquanto reunião dialógica de consciências polifônicas, ambiente de aprendizagem cooperativa.

Esta análise, além da reflexão acerca das aprendizagens construídas nos chats, possibi- lita vivenciar a crítica dialógica, a autoria, a polifonia e o dialogismo apontados por Bakhtin (2003). A interação entre os sujeitos- leitoresouvintes/ respondentes é a grande responsável pela construção estética, a base sobre a qual nos manifestamos discursivamente e o objetivo do nosso dizer. A responsividade nos cerca, invoca-nos e nos faz autores de uma única e infinda história.

Das discussões sobre o pensamento bakhtinano, a uma busca de mais informações; da troca destas informações, via correio eletrônico, à escrita coletiva e à posterior análise do corpus. Teoria e vivência a partir da teoria bakhtiniana são as considerações finais apresentadas na próxima seção.

\section{Considerações Finais}

Em um cenário amparado pelo desenvolvimento de metodologias e posturas interativas, o mais coerente é referenciar os espaços que, de forma interessante e peculiar, promovem a construção cooperativa do conhecimento. O objetivo primeiro do trabalho, a análise de interações em um ambiente telemático, a partir da ótica de um outro - Bakhtin -, possibilitou ao grupo de autores vivenciar o dialogismo e a autoria em um registro mais polifônico.

O trabalho foi, portanto, construído coletivamente: é repleto de vozes, questionamentos, sentidos, percepções, que, complementarmente, teceram um só texto - enunciado que se soma à teia inconclusa, à qual dá a sua singela contribuição. A intenção era seguir o caminho tortuoso das relações dialógicas, onde não há certo nem errado, eu - isso, e, sim, eu - tu/outro(s), ou seja, o nós.

Para tanto, as negociações entre os integrantes do grupo, mostrando como a criação se organiza, foi entrelaçada em processos múltiplos e plurais de autoria. A utilização de um editor de texto coletivo ${ }^{5}$ para a elaboração deste artigo também colaborou para que a teia coletiva se desenvolvesse, livre e minimamen-

${ }^{5} \mathrm{O}$ Editor de Texto Coletivo (ETC) foi desenvolvido pelo NUTED/UFRGS e é baseado na teoria piagetiana na qual entende-se que o conhecimento ocorre pela interação entre sujeito e objeto, e que não se encontra pré-existente em nenhum dos pólos, mas sim, na interação. Por isso, suas funcionalidades tornam possível o máximo de trocas de idéias entre os autores do texto, sem deixar de respeitar o tempo, a individualidade e os processos de cada um. Seu objetivo é tornar o trabalho colaborativo e/ou cooperativo de acordo com a preferência do usuário. Disponível em: <http://homer.nuted. edu. ufrgs. br/etc/ > 
te sistematizada.

Assim, ao abordar a autoria no chat e ao fazer a construção coletiva, o grupo de autores também passou a analisar a sua própria construção polifônica e dialógica, percebendo que as diferentes experiências cognitivas acabam por delinear o movimento dialógico concernente à feitura deste trabalho. Cada integrante acabou por posicionar-se e, na interação com os outros, sugeriu, interferiu, resignificou a escrita deste trabalho, também ele um enunciado. Um enunciado que, busca responder a enunciados anteriores, em específico, aos enunciados trocados durante a disciplina e cujos registros constituíram corpus sobre os quais o grupo realizou, como pesquisadores, um exercício de compreensão e que aponta para novos enunciados, novas escritas e novos exercícios de compreensão.

Assim, este trabalho, com suas especificidades, enunciado construído a várias mãos, que colaboram para dar visibilidade a uma autoria delineada de forma coletiva. Esta autoria também esteve entremeada ao estruturar a escrita e analisar as discussões no ambiente bate-papo, este foi reconhecido como um espaço de convivência no qual os sujeitos têm a possibilidade de, por meio da interação, modificarem a si mesmos, ao outro - o referido supradestinatário - e ao meio, o que retrata um acoplamento estrutural ${ }^{6}$.

Percebeu-se que, na interação que ocorre na funcionalidade bate-papo, autores, leitores e (con-)texto(s) se articulam em um enunciado que é construído na corrente ativa da vida (BAKHTIN, 1976). Compreender Bakhtin, neste ambiente telemático, significa compreender que "[...] o enunciado reflete a interação entre falante(s) e ouvinte(s)-respondente(s), bem como o produto e a fixação, no material verbal, de um ato de comunicação viva entre eles." (BAKHTIN, 1976, p. 18)

\section{Referências}

AXT, Margarete. Comunidades Virtuais de Aprendizagem e Interação Dialógica: do corpo, do rosto e do olhar. Filosofia Unisinos, São Leopoldo, v. 7, n. 3, p. 256-268, set./dez. 2006.

AXT, Margarete; MARASCHIN, Cleci. Prática Pedagógica Pensada na Indissociabilidade Conhecimento-Subjetividade. Educação e Realidade, Porto Alegre, v. 21, n. 1, p. 57-80, 1997.

BAKHTIN, Mikhail. Dircourse in life and discourse in art: concerning sociological poetics in Freudianism: a marxist critique. New York: Academic Press, 1976. Texto mimeografado. Tradução para o português de Cristivão Tezza, para uso didático.

BAKHTIN, Mikhail. Marxismo e Filosofia da Linguagem. 8. ed. São Paulo: HUCITEC, 1997a.

BAKHTIN, Mikhail. Estética da Criação Verbal. Tradução de Paulo Bezerra. São Paulo: Ed. Martins Fontes. 2003.

BEILER, Adriana. A Produção de Redes de Conversação Como Base à Aprendizagem. Porto Alegre: UFRGS, 2004. Tese (Doutorado em Informática na Educação) - Centro Interdisciplinar de Novas Tecnologias na Educação, Universidade Federal do Rio Grande do Sul, 2004, Porto Alegre, BR-RS.

BERNARDES, Alexandra Sexto; VIEIRA, Paula Michele Teixeira. No Discurso Produzido em Salas de BatePapo na Internet: a descoberta de um espaço de produção de linguagem. In: REUNIÃO ANUAL DA ASSOCIAÇÃO NACIONAL DOS PESQUISADORES EM EDUCAÇÃO, 24., 2001, Caxambu. Anais. Caxambu: ANPED, 2001. Disponível em: <http://www.anped.org.br/reunioes/24/T1096468548691.doc> Acesso em: 10. mar. 2008.

\footnotetext{
<?> "A correspondência espaço-temporal efetiva entre as mudanças de estado do organismo e as mudanças de estado do meio, enquanto o sistema permanece se auto-produzindo." (MATURANA 2002, p. 142) No caso específico do bate-papo em um ambiente virtual de aprendizagem, pode-se dizer que existe primeiro um acoplamento com o ambiente, com o espaço e depois com a ferramenta para que a interação possa ocorrer.
} 
FARACCO, Carlos Alberto. Autor e Autoria. In: BRAIT, Bete (Org.). Bakhtin: conceitos-chave. 4. ed. São Paulo: Ed. Contexto, 2007. V. 1, p. 37-60.

FIEDLER-FERRARA, Nelson. Literatura e Complexidade. In: CASTRO, Gustavo de; CARVALHO, Edgard de Assis; ALMEIDA, Maria da Conceição (Org.). Ensaios da Complexidade. Porto Alegre: Ed. Sulina. 1997. P. 75-89.

MATURANA, Humberto; VARELA, Francisco. A Árvore do Conhecimento: as bases biológicas da compreensão humana. São Paulo: Palas Athena, 2001.

SOBRAL, Adail. Ético e Estético: na vida, na arte e na pesquisa em ciências humanas. In: BRAIT, Bete (Org.). Bakhtin: conceitos-chave. 4. ed. São Paulo: Ed. Contexto, 2007. V. 1, p. 103-120.

STAM, Robert. Bakhtin: da teoria literária à cultura de massa. Tradução de Heloísa Jahn. São Paulo: Ática: 1992.

TODOROV, Tzvetan. Prefácio à Edição Francesa. In: BAKHTIN, Mikhail. Estética da Criação Verbal. Tradução de Maria Ermantina de Almeida Prado Galvão. São Paulo: Ed. Martins Fontes, 2003. P. xiii-xxxii.

VYGOTSKY, Lev. Fomação Social da Mente: desenvolvimento dos processos psicológicos superiores. São Paulo: Ed. Martins Fontes, 1988.

Recebido em julho de 2008.

Aprovado para publicação em setembro de 2008.

\section{Cláudia Zank}

Mestranda em Educação na Pós Graduação em Educação na Universidade Federal do Rio Grande do Sul (PPGEDU/UFRGS). Especialista em Educação a Distância

claudiazank@gmail.com

\section{Cristiani de Oliveira Dias}

Mestranda em Educação na Pós Graduação em Educação na Universidade Federal do Rio Grande do Sul (PPGEDU/UFRGS). Especialista em Informática na Educação. Bacharel em Informática.

cristianideoliveiradias@gmail.com

\section{Evandro Alves}

Doutor em Educação. Mestre em Educação. Licenciado em Pedagogia pela Universidade Federal do Rio Grande do Sul (UFRGS).

evandarilho@gmail.com

\section{Karla Marques da Rocha}

Doutora em Informática na Educação pela Universidade Federal do Rio Grande do Sul (UFRGS). Mestre em Educação karlarocha@terra.com.br

\section{Lilian Teresinha J ohann}

Especialista em Linguagem, Ensino e Tecnologias e Licenciada em Letras pela Unidade Integrada Vale do Taquari de Ensino Superior (UNIVATES).

lilian@certelnet.com.br 